Luís Felipe Leite Martins',II

Joaquim Gonçalves Valente ${ }^{\mathrm{II}, \mathrm{III}}$

Luiz Claudio Santos Thuler',IV
Instituto Nacional de Câncer. Rio de Janeiro, RJ, Brazil

" Instituto de Medicina Social. Universidade do Estado do Rio de Janeiro. Rio de Janeiro, RJ, Brazil

III Escola Nacional de Saúde Pública Sérgio Arouca. Fundação Oswaldo Cruz. Rio de Janeiro, RJ, Brazil

Iv Universidade Federal do Estado do Rio de Janeiro. Rio de Janeiro, RJ, Brazil

Correspondence:

Luís Felipe Leite Martins

R. dos Inválidos $212-3^{\circ}$ andar - Centro

20231-048 Rio de Janeiro, RJ, Brazil

E-mail: Ifmartins@inca.gov.br

\section{Factors related to inadequate cervical cancer screening in two Brazilian state capitals}

\section{Fatores associados ao rastreamento inadequado do câncer cervical em duas capitais brasileiras}

\begin{abstract}
OBJECTIVE: To analyze factors associated with cervical cancer screening failure.

METHODS: Population-based cross-sectional study with self-weighted two-stage cluster sampling conducted in the cities of Fortaleza (Northeastern Brazil) and Rio de Janeiro (Southeastern Brazil) in 2002. Subjects were women aged 25-59 years in the last three years prior to the study. Data were analyzed through Poisson regression using a hierarchical model.
\end{abstract}

RESULTS: The proportion of women who did not undergo the Pap smear test in Fortaleza and Rio de Janeiro was 19.1\% (95\% CI: 16.1;22.1) and $16.5 \%$ (95\% CI: 14.1;18.9), respectively. Higher prevalence ratios of cervical cancer screening failure in both cities were seen among women with low education and low per capita income, old age, unmarried, who never underwent mammography, clinical breast examination, and blood glucose and cholesterol level testing. Smokers also had lower screening rates compared to non-smoker women and this difference was only statistically significant in Rio de Janeiro.

CONCLUSIONS: The study findings point to the need of intervention focusing particularly women in worse socioeconomic conditions and access to healthcare, old-aged and unmarried. Education activities must prioritize screening of asymptomatic women and early diagnosis for symptomatic women and access to adequate diagnostic methods and treatment should be provided.

DESCRIPTORS: Vaginal Smears. Uterine Cervical Neoplasms, diagnosis. Women's Health. Cross-Sectional Studies. 


\section{RESUMO}

OBJETIVO: Analisar fatores associados à não-realização do exame de Papanicolaou.

MÉTODOS: Estudo transversal, de base populacional, com amostragem por conglomerados com dois estágios de seleção e autoponderada em 2002. As participantes foram mulheres de 25 a 59 anos de idade nos três anos anteriores à pesquisa, nos municípios de Fortaleza $(\mathrm{CE})$ e Rio de Janeiro $(\mathrm{RJ})$. Os dados foram analisados por regressão de Poisson por meio de modelo hierárquico.

RESULTADOS: O percentual de mulheres não submetidas ao exame de Papanicolaou foi de 19,1\% (IC 95\%: 16,1;22,1) em Fortaleza e 16,5\% (IC 95\%: 14,1;18,9) no Rio de Janeiro. As maiores razões de prevalência para a não-realização do exame nas duas localidades foram entre mulheres com baixa escolaridade, de menor renda per capita, com idade mais avançada, nãocasadas e que nunca foram submetidas à mamografia, ao exame clínico das mamas e aos exames de glicemia e colesterolemia. Além disso, as fumantes foram menos submetidas ao exame de Papanicolaou quando comparadas às demais mulheres, sendo a diferença estatisticamente significativa somente no Rio de Janeiro.

CONCLUSÕES: Os achados apontam a necessidade de intervenção principalmente em mulheres de piores condições socioeconômicas e de acesso à saúde, com idade mais avançada e não-casadas. As atividades de educação para o diagnóstico precoce e para o rastreamento em mulheres sintomáticas e assintomáticas devem ser priorizadas com garantia de acesso aos métodos de diagnóstico e tratamento adequados.

\section{DESCRITORES: Esfregaço Vaginal. Neoplasias do Colo do Útero, diagnóstico. Programas de Rastreamento. Saúde da Mulher. Estudos Transversais.}

\section{INTRODUCTION}

Cervical cancer accounts for about $15 \%$ of all cancers in women, and it is today the second most common one in women worldwide. In developing countries, it ranks first among all cancers in women while in developed countries cervical cancer is the sixth most common type of cancer. The highest incidence rates of cervical cancer are seen in Latin America and the Caribbean, parts of Africa, South and East Asia, while in North America, Australia and North and West Europe, the rates are lower. ${ }^{a}$ In Brazil, between 1991 and 2001, age standardized incidence rates ranged from 14.3 per 100,000 women in Salvador to 50.7 per 100,000 women in the Federal District. ${ }^{\text {b }}$ In 2005, cervical cancer accounted for $6.7 \%$ of all cancer deaths in Brazil, the fourth most common cause of death. ${ }^{c}$
Age-standardized mortality rates for cervical cancer in Brazil remain quite high and stable over time: $4.97 / 100,000$, in 1979 , and $5.3 / 100,000$, in 2005 , corresponding to a relative percent variation of $6.5 \%$. ${ }^{\mathrm{c}}$

For WHO, a coverage of $80.0 \%$ of screening test among women aged 35 to 59 years old would cause an impact on morbidity and mortality indicators, which can be seen in four years after the implementation of early detection. In countries where effective screening programs are in place, $65.0 \%$ to $70.0 \%$ reduction in mortality can then be expected.

Despite the growing knowledge in this field, a more effective approach for cervical cancer management continues to be screening using the Papanicolaou (Pap)

\footnotetext{
a International Agency for Research on Cancer. IARC confirms the efficacy of cervix cancer screening for women 25-65 in reducing mortality. Lyon; 2004 [cited 2007 Nov 29]. Available from: http://www.iarc.fr/en/Media-Centre/IARC-Press-Releases/Archives-2006-2004/2004/IARCconfirms-efficacy-of-cervix-cancer-screening-for-women-25-65-in-reducing-mortality

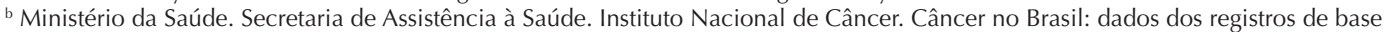
populacional. Brasília; 2003 [cited 2007 Nov 29]. Available from: http://www.inca.gov.br/regpop/2003

${ }^{c}$ Ministério da Saúde. DATASUS - Departamento de Informática do SUS [Internet]. Brasília; 2007 [cited 2007 Nov 29]. Available from: http:// www.datasus.gov.br
} 
test. A systematic literature review ${ }^{4}$ showed that published cross-sectional studies are not very comprehensive, mainly those based on probabilistic samples on Pap test coverage in Brazil. Most studies are carried out in large cities in the Southern and Southeastern regions. Moreover, there is little methodological standardization concerning sampling and profile of women investigated which makes it difficult comparison of studies. Despite that, there is a tendency toward temporal growth in the proportion of women undergoing at least one Pap test. Two studies carried out in the 1980's showed coverage rates of 53.1 and $68.9 \%$ during lifetime, while a household survey carried out between 2002 and 2003 reported rates ranging from 73.4 to $92.9 \%$; however, two population-based studies carried out nationwide in 2003 showed coverage rates below $70.0 \%$ within the previous three years.

These Brazilian studies pointed out common variables seen among women who did not undergo the Pap test. In 1987 Nascimento et $\mathrm{al}^{5}$ reported that being between 15 and 24 years of age, single, of low socioeconomic level, not having consulted a doctor in the year preceding the study, not having used oral contraceptives and not having performed breast self-examination in the previous year were factors associated with cervical cancer non-screening. Pinho et $\mathrm{al}^{6}$ reported that the main reasons for not undergoing testing were: not having gynecological problems, being embarrassed or afraid of undergoing testing, and reported difficulty in gaining access to a health care unit. In another study, Costa et $\mathrm{al}^{3}$ concluded that the lower the social condition the less women would undergo cervical screening and that coverage was lower in older women. Quadros et $\mathrm{al}^{8}$ showed that black and low income women were proportionally less likely to undergo screening. Finally, Cezar et $\mathrm{al}^{2}$ reported that the highest prevalence ratios for non-screening were found among black or mixed skin color women, with less than 20 years of age, with low family income and low education, living alone and who had first given birth after 25 years of age.

As more in-depth information on cervical cancer nonscreening is needed, the present study aimed to analyze factors associated with cervical cancer screening failure in two large Brazilian cities.

\section{METHODS}

The present study is a subset of a larger survey about risk behaviors and reported morbidity of noncommunicable diseases and damages carried out in 2002 and
2005 in 18 Brazilian cities. It is a population-based cross-sectional study and its details are described elsewhere. ${ }^{a}$ Data on women aged 25-59 years, living in two Brazilian state capitals (Rio de Janeiro and Fortaleza) were included. The cities were chosen considering the deep socioeconomic differences between them: Rio de Janeiro is located in the most developed region (Southeast) of Brazil, has low illiteracy rate (4.4\%), low proportion of poor people $(15.4 \%)$, and good health insurance coverage $(50.9 \%)$; Fortaleza is in the Northeastern region, has high illiteracy rate $(11.2 \%)$, high proportion of poor people $(42.4 \%)$, and inadequate health insurance coverage $(25.7 \%)$. b,c

In order to determine the sample size for each municipality, a 95\% confidence interval, a relative precision of $10.0 \%$ and the ability to adequately obtain a $27.0 \%$ prevalence - which is the estimate prevalence for smoking, one of the most important epidemiological risk factors for non-communicable diseases - were taken into consideration. Self-weighted two-stage cluster sampling was used in each municipality. Census tracts were systematically selected, proportionally to the number of private households. In each census tract, all households were recorded, classified as occupied, closed, empty, occasional use and non-residential. Then they were selected in a systematic way. A total of 1,021 households in Fortaleza, and 1,716 in Rio de Janeiro were visited, and 760 and 987 women between 25-59 years old were included in the sample, respectively. All non-interviewed households and 30\% sample of the interviewed ones were revisited by trained supervisors to ensure coverage and quality of information. It was not possible to obtain information in $4.6 \%$ and $14.0 \%$ of the households in Rio de Janeiro and Fortaleza, respectively, because people were not present, refused to participate in the study or other reasons.

A household questionnaire was used to collect sociodemographic information, and other information was obtained from a specific questionnaire directed to adult population. Questionnaires were tested before being applied.

The following predictive variables were analyzed: age ( 25 to 34 years; 35 to 49 years; and 50 to 59 years), schooling (zero to three years; four to seven years; eight to ten years; and 11 years and more), marital status (unmarried; and married or living with a partner), per capita income ( $\leq 3$ monthly minimum wages [MMWs]; and >3 MMWs), cholesterol and blood glucose levels (if any), mammography and clinical breast examination (if

\footnotetext{
${ }^{a}$ Coordenação de Prevenção e Vigilância, Instituto Nacional de Câncer. Inquérito domiciliar sobre comportamentos de risco e morbidade referida de doenças e agravos não transmissíveis: Brasil, 15 capitais e Distrito Federal 2002-2003. Rio de Janeiro; 2004 [cited 2005 Jan 10 ]. Available from: http://www.inca.gov.br/inquerito

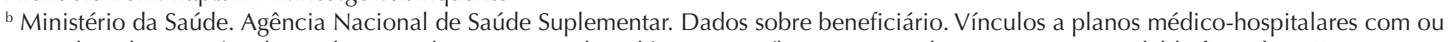
sem odontologia e vínculos a planos exclusivamente odontológicos. Brasília; 2005 [cited 2005 Oct 29]. Available from: http://www.ans.gov. br/portal/upload/dados_setor/dadossobrebeneficiarios/Tabelas\%20-\%20Beneficiários\%20Total.xls

c Ministério da Saúde. DATASUS - Departamento de Informática do SUS [Internet]. Brasília; 2007 [cited 2007 Nov 29].

Available from: http://www.datasus.gov.br
} 
any), and smoking habits. Marital status and schooling were defined according to the Instituto Brasileiro de Geografia e Estatística (Brazilian Institute of Geography and Statistics, IBGE) criteria. ${ }^{\text {a Smoking habits }}$ were defined according to CDC criteria, ${ }^{b}$ i.e., cigarette smokers were defined as people who have smoked 100 or more cigarettes in their lifetime.

A software in Delphi, using the Oracle platform for data input, was developed. For data analysis Stata 8.0 was used as the "survey" module provides data analysis of epidemiological surveys with complex sampling strategies. Proportion and association estimates, and their respective $95 \%$ confidence intervals $(95 \% \mathrm{CI})$, were calculated using the cluster sampling plan. Statistical significance was tested through Pearson's chi-square test, which, based on the sampling strategy, was converted to an F-test (Fisher-Snedocor). ${ }^{\mathrm{c}}$

To measure the rate of association between the predictive variables and the outcome, crude and adjusted prevalence ratios (controlled for possible interactions and confounders), and their respective confidence intervals were calculated through the Poisson regression model, which uses the prevalence ratio as the effect measure. It allows more accurate interpretations since the odds ratio overestimates the magnitude in highly prevalent conditions. ${ }^{1,11}$ Some variables were recategorized or changed, as follows: schooling, classified as incomplete elementary school (zero to seven years of schooling), and complete elementary school and more (eight years of schooling or more); smoking habits, defined as smoker or non-smoker (non-smoker or former smoker); and access to blood glucose and cholesterol testing, categorized as "yes" when both tests were performed, and "no" when none or only one was performed. The significance of each variable in the model was assessed through the Wald test. ${ }^{\mathrm{c}}$ In the analysis, p-values lower than 0.05 were considered statistically significant. In multivariate analysis, variables were included following a previously determined hierarchical framework based on the literature review. ${ }^{4}$

In this model some variables were assumed to mediate their effects through other variables as well as directly. Variables were selected based on biological plausibility and association ( $\mathrm{p}$-value lower than 0.05 ) with outcome according to the bivariate analysis. The first level included the variable age; the second level included the variables schooling, marital status, and per capita income; and the third level included blood glucose and cholesterol levels, mammography, clinical breast examination, and smoking habits.
The study was carried out in a way to protect the individual's privacy, thus ensuring anonymous and voluntary participation. All participants signed a free informed consent. The study was approved by the Research Ethics Committee of the Brazilian Institute of Cancer, and conducted in accordance with all recommendations of the National Health Council.

\section{RESULTS}

The characteristics of the population studied are described in Table 1. The proportion of women not undergoing the Pap test within the previous three years was $19.1 \%$ (95\% CI: $16.1 ; 22.1)$ and $16.5 \%$ (95\% CI: $14.1 ; 18.9)$ in Fortaleza and Rio de Janeiro, respectively $(p=0.18)$. The lower the education and per capita income, the higher the proportion of screening failure in both cities (Table 2). Moreover, smokers, unmarried women, those who had never undergone a mammography, clinical breast examination, cholesterol and blood glucose testing underwent less Pap tests in both cities. Age was the sole variable included in the model which was not statistically associated with the outcome.

The analysis of gross prevalence ratios (Table 3 ) showed that all variables, except age in Fortaleza, were associated with screening failure in both cities and thus were included in the multivariate model. Plausible interactions were tested. These interactions were not incorporated into the final model since prevalence ratios lost precision, probably due to the low rate of subset outcomes. Changes in effect were seen only in the third level.

Women with incomplete elementary school, unmarried, and with lower per capita income showed higher prevalence ratios of screening failure in both cities. The same was seen among women who had never undergone a mammography, clinical breast examination, and blood glucose and cholesterol testing. In Rio de Janeiro, smokers showed a statistically significant difference of screening failure compared to other women.

\section{DISCUSSION}

The present study showed that women with low education, low per capita income, older age, unmarried, smoker, who had never undergone a mammography, clinical breast examination, or blood glucose and cholesterol testing were less screened for cervical cancer in both cities. Smokers showed higher prevalence of screening failure, but this association was only statistically significant in Rio de Janeiro.

a Instituto Brasileiro de Geografia e Estatística. Censo Demográfico - 2000. Educação: resultados da amostra. Rio de Janeiro; 2000 [cited 2006 Feb 8]. Available from: http://www.ibge.gov.br/home/estatistica/populacao/censo2000/educacao/tabela_regioes.shtm

${ }^{\mathrm{b}}$ Centers for Disease Control and Prevention. National Center for Disease Prevention and Health Promotion. Division of Adult and Community Health. Behavioral Surveillance Branch. 2001 BRFSS summary prevalence report. Atlanta; 2001 [cited 2006 Feb 8]. Available from: http://www.cdc.gov/brfss/pdf/2001 prvrpt.pdf

c Pessoa DGC, Nascimento Silva PL. Análise de dados amostrais Complexos. Associação Brasileira de Estatística, São Paulo 1998. 
Table 1. Epidemiological and clinical characteristics of women studied. Fortaleza and Rio de Janeiro, Northeast and Southeast Brazil, 2002-2005.

\begin{tabular}{|c|c|c|c|c|c|c|}
\hline \multirow[b]{2}{*}{ Variable } & \multicolumn{3}{|c|}{ Fortaleza } & \multicolumn{3}{|c|}{ Rio de Janeiro } \\
\hline & $\begin{array}{l}\text { Screened } \\
(\mathrm{n}=615)\end{array}$ & $\begin{array}{l}\text { Not screened } \\
\quad(n=145)\end{array}$ & Total $(n=760)$ & $\begin{array}{l}\text { Screened } \\
(\mathrm{n}=824)\end{array}$ & $\begin{array}{l}\text { Not screened } \\
\qquad(n=163)\end{array}$ & Total $(n=987)$ \\
\hline $\begin{array}{l}\text { Age (years) Mean, } \\
\%(95 \% \mathrm{Cl})\end{array}$ & $\begin{array}{c}38.9 \\
(38.0 ; 39.7)\end{array}$ & $\begin{array}{c}39.4 \\
(37.6 ; 41.2)\end{array}$ & $\begin{array}{c}39.0 \\
(38.2 ; 39.8)\end{array}$ & $\begin{array}{c}40.8 \\
(40.1 ; 41.5)\end{array}$ & $\begin{array}{c}42.0 \\
(40.3 ; 43.8)\end{array}$ & $\begin{array}{c}41.0 \\
(40.4 ; 41.6)\end{array}$ \\
\hline $\begin{array}{l}\text { Schooling (complete } \\
\text { elementary school), } \\
\%(95 \% \mathrm{Cl})\end{array}$ & $\begin{array}{c}60.7 \\
(54.0 ; 67.4)\end{array}$ & $\begin{array}{c}41.5 \\
(31.1 ; 51.9)\end{array}$ & $\begin{array}{c}57,0 \\
(50.6 ; 63.5)\end{array}$ & $\begin{array}{c}75.6 \\
(71.3 ; 79.9)\end{array}$ & $\begin{array}{c}47.5 \\
(38.8 ; 56.1)\end{array}$ & $\begin{array}{c}71.0 \\
(66.3 ; 75.8)\end{array}$ \\
\hline $\begin{array}{l}\text { Marital status (married } \\
\text { or lived in living with a } \\
\text { partner), } \%(95 \% \mathrm{Cl})\end{array}$ & $\begin{array}{c}61.5 \\
(56.7 ; 66.2)\end{array}$ & $\begin{array}{c}50.0 \\
(40.0 ; 58.0)\end{array}$ & $\begin{array}{c}59.1 \\
(54.7 ; 63.5)\end{array}$ & $\begin{array}{c}65.5 \\
(68.7 ; 68.8)\end{array}$ & $\begin{array}{c}49.1 \\
(41.2 ; 56.9)\end{array}$ & $\begin{array}{c}62.8 \\
(59.8 ; 65.8)\end{array}$ \\
\hline $\begin{array}{l}\text { Per capita income }(\leq 3 \\
\text { MMWs), } \%(95 \% \mathrm{Cl})\end{array}$ & $\begin{array}{c}76.1 \\
(68.2 ; 84.1)\end{array}$ & $\begin{array}{c}91.8 \\
(87.0 ; 96.6)\end{array}$ & $\begin{array}{c}79.1 \\
(71.8 ; 86.4)\end{array}$ & $\begin{array}{c}64.0 \\
(56.8 ; 71.2)\end{array}$ & $\begin{array}{c}81.2 \\
(74.4 ; 88.0)\end{array}$ & $\begin{array}{c}67.0 \\
(60.0 ; 73.8)\end{array}$ \\
\hline $\begin{array}{l}\text { Smoking habits (regular } \\
\text { smokers), \% (95\% Cl) }\end{array}$ & $\begin{array}{c}15.9 \\
(13.0 ; 18.9)\end{array}$ & $\begin{array}{c}29.6 \\
(21.3 ; 38.0)\end{array}$ & $\begin{array}{c}18.5 \\
(15.5 ; 21.6)\end{array}$ & $\begin{array}{c}18.2 \\
(15.4 ; 21.0)\end{array}$ & $\begin{array}{c}36.8 \\
(27.6 ; 46.0)\end{array}$ & $\begin{array}{c}21.3 \\
(18.4 ; 24.2)\end{array}$ \\
\hline $\begin{array}{l}\text { Mammography } \\
\text { (never), \% (95\% Cl) }\end{array}$ & $\begin{array}{c}64.2 \\
(58.5 ; 69.9)\end{array}$ & $\begin{array}{c}93.1 \\
(97.3 ; 98.9)\end{array}$ & $\begin{array}{c}69.7 \\
(64.7 ; 74.8)\end{array}$ & $\begin{array}{c}49.8 \\
(45.2 ; 54.5)\end{array}$ & $\begin{array}{c}82.8 \\
(27.6 ; 46.0)\end{array}$ & $\begin{array}{c}55.3 \\
(50.9 ; 59.7)\end{array}$ \\
\hline $\begin{array}{l}\text { Clinical breast } \\
\text { examination (at least } \\
\text { one), \% }(95 \% \mathrm{Cl})\end{array}$ & $\begin{array}{c}89.4 \\
(86.7 ; 92.2)\end{array}$ & $\begin{array}{c}43.4 \\
(34.8 ; 48.8)\end{array}$ & $\begin{array}{c}80.7 \\
(77.2 ; 84.1)\end{array}$ & $\begin{array}{c}92.5 \\
(90.3 ; 94.9)\end{array}$ & $\begin{array}{c}53.4 \\
(44.3 ; 62.4)\end{array}$ & $\begin{array}{c}86.1 \\
(83.2 ; 89.0)\end{array}$ \\
\hline $\begin{array}{l}\text { Blood glucose (tested), } \\
\%(95 \% \mathrm{Cl})\end{array}$ & $\begin{array}{c}62.8 \\
(58.8 ; 66.8)\end{array}$ & $\begin{array}{c}40.0 \\
(31.2 ; 52.0)\end{array}$ & $\begin{array}{c}58.4 \\
(54.6 ; 62.3)\end{array}$ & $\begin{array}{c}79.6 \\
(76.3 ; 83.0)\end{array}$ & $\begin{array}{c}57.8 \\
(50.1 ; 65.4)\end{array}$ & $\begin{array}{c}76.1 \\
(72.6 ; 79.5)\end{array}$ \\
\hline Cholesterol levels (tested) & $\begin{array}{c}61.2 \\
(56.2 ; 66.2)\end{array}$ & $\begin{array}{c}33.1 \\
(25.0 ; 41.2)\end{array}$ & $\begin{array}{c}55.8 \\
(51.0 ; 60.6)\end{array}$ & $\begin{array}{c}85.2 \\
(82.1 ; 88.4)\end{array}$ & $\begin{array}{c}59.2 \\
(51.0 ; 67.5)\end{array}$ & $\begin{array}{c}81.0 \\
(77.9 ; 84.0)\end{array}$ \\
\hline
\end{tabular}

MMWs = monthly minimum wages.

The results found for schooling, per capita income, and marital status are consistent with other Brazilian studies. The same is seen for age and clinical breast examination. Some studies have found lower rates of cervical cancer screening among younger women (15-24 years old, less than 20 years old, 15-29 years old, 25-29 years old), while others have found them among older age groups (50-69 years old, 60-69 years old, and 55-59 years old). ${ }^{4}$ Nascimento et al, ${ }^{5}$ Costa et $\mathrm{al},{ }^{3}$ and Quadros et $\mathrm{al}^{8}$ found high rates of cervical cancer screening failure among women who had never undergone breast self-examination and did not attend medical visits in the year prior to the study, which was not evaluated in the present study.

One finding, to date not reported in other Brazilian studies, was that smokers underwent less Pap tests compared to other women. It may be explained by the fact that smokers have less healthy habits such as engaging in physical activities, healthy eating, and low alcohol consumption that can also be associated with failure of undergoing preventive examinations such as the Pap test. However, this behavioral indicator needs to be further investigated as a barrier to cervical cancer screening. ${ }^{9}$
Another point must be highlighted: the coverage rates of Pap test in both cities were similar and did not show a statistically significant difference. In regard to the predictive variables, both cities studied had distinct distributions: Rio de Janeiro had older women with higher income and education, higher coverage of mammography, blood glucose and cholesterol testing, which may be explained by high insurance coverage in the city. In 2005, health insurance coverage (proportion of beneficiaries in the whole population) in Rio de Janeiro was $56.3 \%$ while it was $38.4 \%$ in Fortaleza. ${ }^{a}$

In spite of these differences, factors associated with screening failure were similar in both cities, except for smoking, which showed a statistically significant association only in Rio de Janeiro. This difference may be due to the sample size, biological differences among women and specific characteristics of cigarette consumption (type and number of cigarettes smoked, and age when they started smoking, which were not assessed in this study). Other Brazilian studies did not consider the potential interaction and confounders, which may have influenced the results.

As Cesar et $\mathrm{al}^{2}$ and Pinho et $\mathrm{al}^{6}$ have already reported, in the interpretation of these studies, one should bear in

a Ministério da Saúde. Agência Nacional de Saúde Suplementar. Dados sobre beneficiário. Vínculos a planos médico-hospitalares com ou sem odontologia e vínculos a planos exclusivamente odontológicos. Brasília; 2005 [cited 2005 Oct 29]. Available from: http://www.ans.gov. br/portal/upload/dados_setor/dadossobrebeneficiarios/Tabelas\%20-\%20Beneficiários\%20Total.xls 
Table 2. Characteristics of women who did not undergo Pap test in the previous three years. Fortaleza and Rio de Janeiro, Northeast and Southeast Brazil, 2002-2005.

\begin{tabular}{|c|c|c|c|c|c|c|}
\hline \multirow[b]{2}{*}{ Variable } & \multicolumn{3}{|c|}{ Fortaleza } & \multicolumn{3}{|c|}{ Rio de Janeiro } \\
\hline & $\mathrm{n}$ & $\begin{array}{c}\% \text { not screened } \\
(95 \% \mathrm{Cl})\end{array}$ & $\mathrm{p}$ & $\mathrm{n}$ & $\begin{array}{c}\% \text { not screened } \\
(95 \% \mathrm{Cl})\end{array}$ & $\mathrm{p}$ \\
\hline \multicolumn{7}{|l|}{ Age (years) } \\
\hline 25 to 34 & 288 & $19.4(14.8 ; 24.1)$ & \multirow{3}{*}{0.14} & 300 & $15.7(11.5 ; 19.8)$ & \multirow{3}{*}{0.08} \\
\hline 35 to 49 & 338 & $16.6(12.4 ; 20.7)$ & & 453 & $14.3(10.5 ; 18.2)$ & \\
\hline 50 to 59 & 134 & $24.6(16.8 ; 32.5)$ & & 234 & $21.8(15.8 ; 27.8)$ & \\
\hline \multicolumn{7}{|l|}{ Schooling (years) } \\
\hline 0 to 3 & 125 & $29.6(19.9 ; 39.3)$ & \multirow{4}{*}{$<0.001$} & 85 & $36.5(25.6 ; 47.3)$ & \multirow{4}{*}{$<0.00$} \\
\hline 4 to 7 & 193 & $23.8(17.5 ; 30.2)$ & & 197 & $26.4(20.7 ; 32.1)$ & \\
\hline 8 to 10 & 130 & $19.2(12.3 ; 26.2)$ & & 180 & $16.7(11.7 ; 21.6)$ & \\
\hline 11 and more & 292 & $11.6(7.9 ; 15.4)$ & & 512 & $8.8(6.3 ; 11.2)$ & \\
\hline \multicolumn{7}{|l|}{ Marital status } \\
\hline Unmarried & 311 & $23.8(18.5 ; 29.1)$ & \multirow{2}{*}{0.01} & 367 & $22.6(18.2 ; 27.0)$ & \multirow{2}{*}{$<0.001$} \\
\hline Married or living with a partner & 449 & $15.8(12.3 ; 19.3)$ & & 620 & $12.9(10.2 ; 15.6)$ & \\
\hline \multicolumn{7}{|l|}{ Per capita income } \\
\hline$\leq 3 \mathrm{MMWs}$ & 574 & $21.6(18.4 ; 24.8)$ & \multirow{2}{*}{$<0.001$} & 604 & $20.7(18.0 ; 23.7)$ & \multirow{2}{*}{$<0.001$} \\
\hline$>3 \mathrm{MMWs}$ & 152 & $7.2(4.2 ; 10.3)$ & & 298 & $9.7(7.2 ; 13.1)$ & \\
\hline \multicolumn{7}{|l|}{ Smoking habits } \\
\hline Non-smoker & 490 & $15.5(12.1 ; 19.0)$ & \multirow{3}{*}{$<0.001$} & 581 & $14.6(11.8 ; 17.5)$ & \multirow{3}{*}{$<0.001$} \\
\hline Former smoker & 129 & $20.2(12.9 ; 27.5)$ & & 196 & $9.2(5.2 ; 13.2)$ & \\
\hline Regular smoker & 141 & $30.5(22.7 ; 38.3)$ & & 210 & $28.6(21.4 ; 35.8)$ & \\
\hline \multicolumn{7}{|l|}{ Mammography (if any) } \\
\hline No & 530 & $25.5(21.7 ; 29.2)$ & \multirow{2}{*}{$<0.001$} & 546 & $24.7(21.2 ; 28.3)$ & \multirow{2}{*}{$<0.001$} \\
\hline Yes & 230 & $4.3(1.6 ; 7.1)$ & & 441 & $6.3(4.2 ; 8.5)$ & \\
\hline \multicolumn{7}{|l|}{ Clinical breast examination (if any) } \\
\hline No & 147 & $55.8(48.4 ; 63.2)$ & \multirow{2}{*}{$<0.001$} & 137 & $55.5(46.9 ; 64.1)$ & \multirow{2}{*}{$<0.001$} \\
\hline Yes & 613 & $10.3(7.7 ; 12.9)$ & & 850 & $10.2(8.0 ; 12.4)$ & \\
\hline \multicolumn{7}{|l|}{ Blood glucose testing (if any) } \\
\hline No & 315 & $27.6(23.0 ; 32.2)$ & \multirow{2}{*}{$<0.001$} & 235 & $28.9(23.4 ; 34.4)$ & \multirow{2}{*}{$<0.001$} \\
\hline Yes & 445 & $13(9.4 ; 16.7)$ & & 752 & $12.6(10.3 ; 15.0)$ & \\
\hline \multicolumn{7}{|l|}{ Cholesterol levels (if any) } \\
\hline No & 335 & $29.0(24.6 ; 33.3)$ & \multirow{2}{*}{$<0.001$} & 187 & $35.3(28.3 ; 42.2)$ & 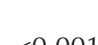 \\
\hline Yes & 424 & $11.3(7.8 ; 14.8)$ & & 799 & $12.1(9.6 ; 14.7)$ & $<0.001$ \\
\hline Total & 760 & $19.1 \%(16.1 ; 22.1)$ & - & 987 & $16.5 \%(14.1 ; 18.9)$ & - \\
\hline
\end{tabular}

MMWs = monthly minimum wages.

mind that information based on women's self-reporting tend to overestimate the rate they undergo examinations, and to underestimate the time from the most recent examination. On the other hand, recall of examinations occurring in the previous three years has been reported to be more accurate than those occurring more than three years before the interview. Another aspect is that studies that deal with this subject assume that all women know what a Pap test is, which may not be true. For instance, women may confuse the Pap test with a gynecological consultation, and vice-versa. The present study sought to minimize this misunderstanding through the questionnaire's previous testing and interviewers' training, besides including a note in the questionnaire to explain what a Pap test is. It is not possible to completely avoid such limitations through a cross-sectional design, although this fact does not invalidate the useful information provided for planning health actions.

An important methodological aspect that should be highlighted is regarding the sample size. The study used a 5.0\% significance level, an estimated prevalence of about $30.0 \%$, and a relative precision of $10.0 \%$. For this reason, lower prevalences, such as those included in this study, may have lost precision, generating wider confidence intervals. 
Table 3. Adjusted Poisson multiple regression analysis of predictive variables for cervical cancer screening failure in the previous three years. Fortaleza and Rio de Janeiro, Northeast and Southeast Brazil, 2002-2005.

\begin{tabular}{|c|c|c|c|c|c|c|c|c|}
\hline \multirow{2}{*}{ Variable } & \multicolumn{4}{|c|}{ Fortaleza } & \multicolumn{4}{|c|}{ Rio de Janeiro } \\
\hline & CPR $(95 \% \mathrm{Cl})$ & $\mathrm{p}$ & APR $(95 \% \mathrm{Cl})$ & $\mathrm{p}$ & CPR $(95 \% \mathrm{Cl})$ & $\mathrm{p}$ & APR $(95 \% \mathrm{Cl})$ & $\mathrm{p}$ \\
\hline \multicolumn{9}{|l|}{$1^{\text {st }}$ level } \\
\hline \multicolumn{9}{|l|}{ Age (years) } \\
\hline 25 to 34 & $1.17(0.83 ; 1.66)$ & 0.36 & $1.17(0.83 ; 1.66)$ & 0.36 & $1.09(0.73 ; 1.62)$ & 0.66 & $1.09(0.73 ; 1.63)$ & 0.66 \\
\hline 35 to 49 & 1.00 & & 1.00 & & 1.00 & & 1.00 & \\
\hline 50 to 59 & $1.49(1.00 ; 2.20)$ & 0.05 & $1.49(1.00 ; 2.20)$ & 0.05 & $1.52(1.03 ; 2.23)$ & 0.03 & $1.52(1.03 ; 2.23)$ & 0.03 \\
\hline \multicolumn{9}{|l|}{$2^{\text {nd }}$ level } \\
\hline \multicolumn{9}{|l|}{ Schooling (years) } \\
\hline 0 to 7 & $1.87(1.33 ; 2.63)$ & 0.001 & $1.73(1.18 ; 2.54)$ & 0.01 & $2.72(2.09 ; 3.53)$ & $<0.001$ & $2.39(1.70 ; 3.34)$ & $<0.001$ \\
\hline 8 and more & 1.00 & & 1.00 & & 1.00 & & 1.00 & \\
\hline \multicolumn{9}{|l|}{ Marital status } \\
\hline Unmarried & $1.50(1.10 ; 2.05)$ & 0.01 & $1.55(1.13 ; 2.13)$ & 0.01 & $1.75(1.32 ; 2.32)$ & $<0.001$ & $1.76(1.30 ; 2.37)$ & $<0.001$ \\
\hline $\begin{array}{l}\text { Married or } \\
\text { living with } \\
\text { a partner }\end{array}$ & 1.00 & & 1.00 & & 1.00 & & 1.00 & \\
\hline \multicolumn{9}{|c|}{ Per capita income } \\
\hline$\leq 3 \mathrm{MMWs}$ & $2.98(1.95 ; 4.58)$ & $<0.001$ & $2.42(1.55 ; 3.79)$ & $<0.001$ & $2.13(1.51 ; 2.99)$ & $<0.001$ & $1.57(1.06 ; 2.32)$ & $<0.02$ \\
\hline$>3 \mathrm{MMWs}$ & 1.00 & & 1.00 & & 1.00 & & 1.00 & \\
\hline \multicolumn{9}{|l|}{$3^{\text {rd }}$ level } \\
\hline \multicolumn{9}{|l|}{ Smoking habits } \\
\hline Smoker & $1.85(1.34 ; 2.56)$ & $<0.001$ & $1.35(0.99 ; 1.83)$ & 0.06 & $2.15(1.55 ; 2.99)$ & $<0.001$ & $1.46(1.06 ; 2.02)$ & 0.02 \\
\hline $\begin{array}{l}\text { Non- } \\
\text { smoker }\end{array}$ & 1.00 & & 1.00 & & 1.00 & & 1.00 & \\
\hline \multicolumn{9}{|c|}{ Mammography (if any) } \\
\hline No & $\begin{array}{c}5.86 \\
(3.10 ; 11.06)\end{array}$ & $<0.001$ & $2.80(1.36 ; 5.75)$ & 0.01 & $3.89(2.65 ; 5.72)$ & $<0.001$ & $2.37(1.53 ; 3.65)$ & $<0.001$ \\
\hline Yes & 1.00 & & 1.00 & & 1.00 & & 1.00 & \\
\hline \multicolumn{9}{|c|}{ Clinical breast examination } \\
\hline No & $5.43(4.01 ; 7.35)$ & $<0.001$ & $3.02(2.18 ; 4.18)$ & $<0.001$ & $5.42(4.00 ; 7.34)$ & $<0.001$ & $2.60(1.87 ; 3.61)$ & $<0.001$ \\
\hline Yes & 1.00 & & 1.00 & & 1.00 & & 1.00 & \\
\hline \multicolumn{9}{|c|}{ Blood glucose and cholesterol levels } \\
\hline No & $2.67(1.83 ; 3.91)$ & $<0.001$ & $1.67(1.12 ; 2.49)$ & 0.01 & $2.82(2.15 ; 3.69)$ & $<0.001$ & $1.58(1.11 ; 2.25)$ & 0.01 \\
\hline Yes (both) & 1.00 & & 1.00 & & 1.00 & & 1.00 & \\
\hline
\end{tabular}

$\mathrm{CPR}=$ crude prevalence rate; $\mathrm{APR}=$ adjusted prevalence rate; $\mathrm{MMWs}=$ monthly minimum wages.

Adjusted models: Level 1: age; Level 2: age + schooling + marital status + per capita income; Level 3: age + schooling + marital status + per capita income + smoking habits + mammography + clinical breast examination + blood glucose and cholesterol levels

Another limitation of the present study was the fact that important variables were not included such as use of oral contraceptives, number of children, past history of gynecological infections, past sexual history (for example, age at sexual initiation or number of partners), and utilization of health services (for example, hospitalizations or number of medical consultations in the last year). In addition, women who had undergone hysterectomy should not have been included in the survey since they do not need to undergo cervical cancer screening. But this data was not available for the entire study population. According to information available for part of these samples, this proportion was $9.0 \%$ in Fortaleza and 9.8\% in Rio de Janeiro.

The strengths of the present study were: analysis of information about two Brazilian state capitals which was not studied before; the adjusted sampling model; and quality control of data collection and input. It should also be highlighted the modeling process, which used a hierarchical method and Poisson regression. This hierarchical method, based on a theoretical model, aimed to avoid that only statistical criteria would determine the 
variable's inclusion in the regression model. ${ }^{10}$ Poisson regression was chosen because it provides prevalence rates straightforwardly as in some situations odds ratios estimated by logistic regression may overestimate prevalence rates. ${ }^{1,11}$

In conclusion, the present study findings show a need of intervening in a group of women with specific characteristics. However, as stated by Pinho \& França-Júnior, ${ }^{7}$ all these variables are individually determined and do not take into consideration other important dimensions associated with the difficulty of undergoing a Pap test

\section{REFERENCES}

1. Barros AJ, Hirakata VN. Alternatives for logistics regression in cross-sectional studies: an empirical comparison of models that directly estimate prevalence ratio. BMC Med Res Methodol. 2003;3:21. DOI:10.1186/1471-2288-3-21

2. Cesar JA, Horta BL, Gomes G, Houlthausen RS, Willrich RM, Kaercher A, et al. Fatores associados à não realização de exame citopatológico de colo uterino no extremo Sul do Brasil. Cad Saude Publica. 2003;19(5):1365-72. DOI:10.1590/S0102311X2003000500014

3. Costa JS, D'Elia PB, Manzolli P, Moreira MR. Cobertura do exame citopatológico na cidade de Pelotas, Brasil. Rev Panam Salud Publica. 1998;3(5):308-13. DOI: 10.1590/S102049891998000500004

4. Martins LFL, Thuler LCS, Valente JG. Cobertura do exame de Papanicolaou no Brasil e seus fatores determinantes: uma revisão sistemática da literatura. Rev Bras Ginecol Obstet. 2005;27(8):485-92. DOI:10.1590/S0100-72032005000800009

5. Nascimento CM, Eluf-Neto J, Rego RA. Pap test coverage in São Paulo municipality and characteristics of the women tested. Bull Pan Am Health Organ. 1996;30(4):302-12. in terms of organizational, programmatic, and social aspects. There should be prioritized education activities for screening of asymptomatic women and early diagnosis of symptomatic women, and access to adequate diagnostic methods and treatment should be ensured.

\section{ACKNOWLEDGMENTS}

The research was financed by the Brazilian Ministry of Health's Health Surveillance Department (SVS), with counterpart funds from the Brazilian National Cancer Institute.
6. Pinho AA, França Jr I, Schraiber LB, D'oliveira AFPL. Cobertura e motivos para a realização ou não do teste de Papanicolaou no Município de São Paulo. Cad Saude Publica. 2003;19(Supl 2):303-13.

7. Pinho AA, França Jr I. Prevenção do câncer de colo do útero: um modelo teórico para analisar o acesso e a utilização do teste de Papanicolaou. Rev Bras Saude Matern Infant. 2003;3(1):95-112. DOI:10.1590/ S1519-38292003000100012

8. Quadros CA, Victora CG, Costa JS. Coverage and focus of a cervical cancer prevention program in southern Brazil. Rev Panam Salud Publica. 2004;16(4): 223-32. DOI:10.1590/S1020-49892004001000001

9. Rakowski W, Clark MA, Ehrich B. Smoking and cancer screening for women ages 42-75: associations in the 1990-1994 National Health Interview Surveys. Prev Med. 1999;29(6 Pt 1):487-95. DOI:10.1006/ pmed.1999.0578

10. Victora CG, Huttly, SR, Fuchs SG, Olinto MT. The role of conceptual framework in epidemiological analysis: a hierarchical approach. Int J Epidemiol. 1997;26(1):224-47. DOI:10.1093/ije/26.1.224

11. Zocchetti C, Consonni D, Bertazzi PA. Relationship between prevalence rate ratios and odds ratios in cross-sectional studies. Int J Epidemiol. 1997;26(1):220-3. DOI:10.1093/ije/26.1.220

Article based on the master's dissertation by LFL Martins presented at the Instituto de Medicina Social of Universidade Estadual do Rio de Janeiro in 2005. 